\title{
Social Networks and Systems Theory
}

\author{
Santiago Gabriel Calise \\ Researcher, CONICET (National Scientific and Technical Research Council), \\ University of Buenos Aires, Faculty of Social Sciences, Instituto de Investigaciones Gino Germani (IIGG) \\ Address: Uriburu $9506^{\circ}$ Floor, Ciudad de Buenos Aires, Argentina C1114AAD \\ E-mail: c_santiago_g20oo@yahoo.com.ar
}

\begin{abstract}
This paper provides a critical assessment of the conceptions of social networks in systems theory. There are two main solutions to the problem: treating networks as systems, or denying them that status. The last group conceives networks as structural couplings (Kämper and Schmidt) or as forms (Fuhse). Among the first group, Luhmann has used the concept to describe the particularities of the societal structure of underdeveloped regions, but he did not delve into a theoretical characterization of the concept. Teubner's version also remained associated with a particular episode, providing no general network theory. Bommes and Tacke establish reciprocity as the central mechanism, which relates different addresses (persons or organizations) through a non-specific future promise of a service in return for a favor. The analysis shows that this account provides the most complete version of the concept, remaining fully compatible with systems theory.

Keywords: reciprocity, structural coupling, address, social relationships, organizations, parasite
\end{abstract}

This paper aims to assess the utilization of the social network concept in systems theory. This notion has a long tradition in the social sciences. Its origin dates back to the sociometric small-group research of the 1940 os and 1950s (Alba, 1981). The aim of these inquiries was the study of the group structure of affective relationships. Simultaneously, it also appeared in anthropological research. Radcliffe-Brown (1940: 2) indicated that "human beings are connected by a complex network of social relations. I use the term social structure to denote this network of actually existing relations". Here, the concept assumed a highly-abstract and descriptive form. Barnes (1954) makes the category slightly more specific, designating the social field made up by the relationships that a person has with other people (some of whom are or are not in touch with each other) as a network. Bott $(1955,2001)$ employs the concept to describe the structural constitution of families. In contrast to networks, organized groups have "common aims, interdependent roles, and a distinctive subculture" (1955: 247). Networks have no common boundary, and their members do not need to have social relations with one another. The second aspect introduces a central feature of Bott's concept, that of connectedness. Connectedness shows the extent to which the acquaintances of a family know and meet one another independently

\footnotetext{
* This work was supported by a Georg Forster Research Fellowship of the Alexander von Humboldt Foundation (3.2 - ARG/1162640).
} 
of the family. As a result, "close-knit" networks have many relationships among the component units, while "loose-knit" ones describe the opposite situation.

In his critical revision of these early developments, Mitchell points out that there is no formal network theory behind those analyses; rather, they derive from commonsense knowledge (1974). For Mitchell, there are three different ways of using this category. First, the pattern of links in a social network explains the behavior of an actor. Second, social networks would comprise of transactions or exchanges between people. Third, network linkages have some normative content. This denotes the actor's understanding of a relationship to the other person's expectation of his behavior. Ultimately, there is only a shift from structural-functional to network terminology, but no alternative data collection or research results.

During the 1970s, the concept attracted the attention of sociologists. In his influential paper called "The Strength of Weak Ties" (1973), Mark Granovetter conceives interpersonal networks as the bridge to relate micro-level interactions to macro-level patterns. Centering the focus of analysis on weak ties, Granovetter considers that weak ties, which act as bridges between network segments, increase social cohesion, while strong ties can lead to overall fragmentation (1983). Another important quality of networks is density. Commonly identified with cohesion, it is "the ratio of the number of ties actually observed to the number theoretically possible" (1976: 1288). Despite the importance attributed to the concept, Granovetter avoided any definition. Thus, its meaning remained highly metaphorical, and devoid of any theoretical depth.

Harrison White started his research on social networks in the 196os, and he arrived at his concept of "netdom" in the 199os, combining the notions of networks and domains. Domains are "the perceived array of such signals -including story sets, symbols, idioms, registers, grammatical patternings, and accompanying corporeal markers- that characterize a particular specialized field of interaction. Such domains are jointly perceived and produced by (at least some subset of) actors, who sustain those domains across the flow of social settings in more or less routinized or self-reflective ways" (Mische \& White, 1998: 702). Networks are "sets of actors jointly positioned in relation to a given array of ties (for example, friendship, advice, cowork, church membership, political alliance, business transactions, information exchange, and so on). Each type of tie is accompanied by a set of stories (along with associated discursive signals) that are held in play over longer or shorter periods of time, usually not limited to single setting or episode" (703). White distinguishes between networks and ties, considering that networks shape and connect ties. Networks work as a broader temporal-relational social space, which can be abstracted from cumulated interactions. White considers that both ties and networks are theoretical abstractions, that is, an observer's coding of relationships between pairs of people (Azarian, 2005). As Azarian suggests, a problem related to these concepts, which is common to most social networks theories, is the criterion followed to distinguish "a relationship from the sheer encounters and unrepeated interactions among strangers. That is, we are not told whether a certain minimum degree of durability, intensity, frequency, 
regularity or reciprocity of interaction is necessary to decide whether there exists a relationship between any given pair of actors" (37).

Another important aspect of White's theory is that both networks and ties are dynamic constructions rather than ossified canals between nodes which would remain invariable, as in old-fashioned network conceptions (Azarian, 2005). Furthermore, White incorporates the cultural dimension that is completely absent in previous versions. The category of "story" integrates the perceptions and interpretations developed by actors about their ties.

In the actor-network theory (ANT), the network concept is also of central importance. Despite its significance, Latour and other ANT supporters were quite reluctant to provide a definition. It was only in the late 1990s that Latour voiced criticism against this notion. The common technical sense of network related to urban transport or computer systems, characterized by a set of rigorous paths, by a few nodes of strategic meaning, and by an instantaneous access to information would be the opposite of what Latour and his colleagues meant by "network" (1996; 1999). As Latour says, "[a]n actor-network may lack all the characteristics of a technical network - it may be local, it may have no compulsory paths, no strategically positioned nodes" (1996:369). Latour also tried to distance himself from the traditional social network research, understood as the study of the social relations of individual human actors. In contrast, Latour claims ANT is a change of topology which asks the researcher "to think in terms of nodes that have as many dimensions as they have connections" (370). The French philosopher identifies three properties of networks. The first one is that the network concept allows the researcher to "get rid of 'the tyranny of distance' or proximity" (371). The second one is that this category dissolves the micro-macro distinction of social theory, replacing the metaphor of scales with that of connections. The third one is that networks have no inside and outside, since they are all boundaries. In a similar vein, John Law considers that networks are forms of spatiality, which impose "strong restrictions on the conditions of topological possibility" (1999: 7). As a result, a network "tends to limit and homogenize the character of links, the character of invariant connection, the character of possible relations, and so the character of possible entities" (Ibid.).

As this quick review shows, the concept has a large semantic field. The most important notions in this landscape are those of "relationship" and "tie", which also can imply that of "exchange". At a second level, we can find the ideas of "connectedness", "density", and "cohesion", which are less neutral as they entail a certain conception of sociality in terms of "integration", sometimes associated with a Durkheimian interpretation of society. Most recent authors, like Latour or White, explicitly avoided these implications. From a societal perspective, some researchers use this concept to account for particular social phenomena-like kinship — which the categories of "organization" or "group" cannot grasp. A central aspect is the lack of boundaries of those networks. In contrast to this, Latour finds a peculiarity of modernity in networks: "As a first approximation, ANT claims that modern societies cannot be described without recognizing them as having a fibrous, thread-like, wiry, stringy, ropy, capillary character that is never captured by 
the notions of levels, layers, territories, spheres, categories, structures, systems" (1996: 370). This could be a criticism of approaches like Luhmann's systems theory. Therefore, a network concept in systems theory can incorporate some of these elements, such as the notion of "exchange" or that of a network as a sui generis phenomenon. On the contrary, the idea of a system without boundaries would be unacceptable.

In the next section, we will start with the analysis of Luhmann's sparse references to this concept, references which turn up in his attempt to characterize the societal organization of non-central forms of functional differentiation (as in the cases of Brazil and southern Italy). The dissatisfaction provoked by this state of affairs leads us to look for alternate conceptions: Teubner interprets networks as third-order autopoietic systems; Bommes and Tacke put reciprocity at the core of their reflections; Kämper and Schmidt understand networks as a special form of structural coupling; and Fuhse conceives social networks as social relationships. Finally, we will examine the interpretation of networks as parasites.

\section{Luhmann's Network Concept}

As Bommes and Tacke (2007) show, Luhmann uses the network concept in two different ways. The first is mainly descriptive and designates the form of the operative mode of communication. This means that systems are not networks, but their operations have a network-shape. The second defines social networks as a specific social formation. According to the authors, this concept is absent in Luhmann's theorization. Nevertheless, Luhmann also resorted to the network concept to describe the particularity of the societal condition of the non-developed regions of world society (1992, 1995a, 1995b). In these papers, he talks about networks of favors, of patronage, of patron/client relationships, of corruption; networks of help, of assistance and expectable gratitude; networks of postponement of benefits (Vorteilsverschiebungen), and of chains of reciprocity or of fair-weather friendships (Nutzfreundschaften). This enumeration shows the heteroclite nature of the phenomenon (or phenomena) under analysis. Here we can find networks, which imply legal and illegal, moral and immoral, and public and secret behavior. There is no reason to reduce this set of phenomena just to networks of favors and corruption, as Fuhse does (2014).

The most important point of these considerations is that Luhmann, at least in one text (1995a: 254), designates them as systems. Luhmann specifies two conditions under which these systems work. The first one is that families alone cannot safeguard and foster life management. The second is that organizations do not function, or they just function as an allocation of positions under which one has something to offer. Therefore, one has to resort to dyadic relationships managed by a broker. These two circumstances situate us in a societal form where families have already lost their centrality, but where organizations do not work, or their performances do not satisfy the needs of that segment of world society. A new system appears in between families and organizations, which takes advantage of the positions provided by organizations. Someone who has a position in 
an organization (an address) has something to offer to a broker, with whom one can interchange something. The broker and the position in an organization are two structural forms of this system. The form that these relationships assume is oral communication (in high amounts) (1995a, 1995b).

Another characteristic of networks as systems is the nature of the exchanges. Luhmann argues that neither these systems work with a universal medium of exchange, nor they reduce themselves to a quid pro quo rationality of the immediate exchange. This implies the possibility of confronting and exchanging performance equivalents. For Luhmann, this is highly unlikely in modernity. The necessary precondition for this phenomenon is the self-created incapacity of the official order. Without this, the information system of addresses and performance possibilities would collapse.

After these general remarks, Luhmann (1995a: 255) states that networks of reciprocal favors cannot build institutions. They operate ad hoc, based on dyadic relationships, and often with brokers. According to the German sociologist, this makes networks ungraspable. The weak institutionalization of the system is also its strength. As a result, it is not possible to reform, organize, or centralize it. Its reality lies in autonomous forms of inclusion/exclusion (take part or dropout).

These reflections leave some open questions. The first question is if all the characteristics of networks we have reported concern all the networks previously enumerated or just the networks of favors. We can also doubt if Luhmann subsumes all these networks under the networks of favors. There is no reason to equal, for example, the networks of help and the clientelistic networks. This conceptual synecdoche would reduce all these sorts of phenomena under one model, which has nothing of the archetypical.

Another more theoretical question concerns the sort of operation that networks would perform. Regarding this point, there are just vague clues in the texts. If we discard the possibility that networks are organizations, there would be two possibilities: that networks are interaction systems, or that they are a new sort of system. In both interactions and networks predominates orality, but networks, with their complex structures of addresses and mediators, are not reducible to a collection of interactive interchanges. The second possibility implies finding the particular operation that these systems perform. At least in Inklusion und Exklusion, Luhmann considers that the basal resource of these networks is that somebody knows someone, and so forth. In this way, the requests and favors propagate so that, when somebody can help, they cannot refuse it without the risk of being excluded from the net of reciprocal services. This net of reciprocal services generates its mechanisms of exclusion so that someone can become a non-person, that is, someone that no one knows. As a result, even if a person possesses the formal entitlements, they will not get access to the functional system. This description of the "basal resource" gives us an idea of what Luhmann means by "network", but it does not answer the question of the operation of the "network" system. The idea of reciprocity overflies continuously, but it is not possible to identify it with the operation of the system.

Regarding the societal context of the emergence of these networks, Luhmann (1995a) suggests that they can be the remnants of previous societal formations. In stratified so- 
cieties, brokers worked between fixed status positions. With the primacy of functional differentiation and organizational implementation, every position performs intermediary services. In addition, the distinction of property/family will no longer be the spring of resources, and the legal/illegal opportunities of influence offered by the positions in organizations will take that place. This also implies that inclusion and exclusion will no longer differentiate through the family household, but the network of contacts. In this context, Luhmann also points out that, in these networks, one can find the explanation of the phenomena described as corruption in the modern world. Besides, the networks of favors and the postponement of benefits differentiate and operate parasitically. Luhmann states that the allocation of those positions falls, to a large extent, in the sphere of influence of political parties, which are directly and indirectly involved in the networks and upholds them.

From these remarks, it is possible to state that the emergence of networks as systems results from a particular evolutionary way that the functionally-differentiated society took in some regions. There, networks become the key elements in understanding their societal constitution, as it administers the inclusion and exclusion in functional systems. If we go into detail, parasitism seems to describe the relationship that networks establish with both functional systems and organizations. As we have previously seen, organizations provide positions, but they do not work. Regarding functional differentiation, Luhmann points out that resources from functional systems are "alienated" for the cross-connection and maintenance of networks. Nevertheless, the remark concerning the political parties makes the relationship between functional systems and organizations more interesting and complex. Political parties are not just zombie organizations exploited by networks. They have an active role in securing and holding positions, and in the general maintenance of their networks. Parties take part in networks, which could mean that networks are social phenomena that, presumably, encompass organizations and interactions. As a result, they would hold a position in the Ebenendifferenzierung between functional systems and organizations. If this interpretation is correct, the maintenance that political parties exert over the networks does not imply any sort of control over the operations of the networks. They would participate in networks as psychic systems take part in communication, namely, their operativity would be completely divorced.

This use of the network concept was not very innovative. Luhmann's analysis refers to some traditional connotations displayed in classic literature. One of these is the centrality of exchange as the primary interest to participate in a network. In connection with this, networks seem to comprise central nodes (positions in organizations), and some peripheral nodes (people asking for favors). In this regard, networks appear as quite stable structures.

\section{Networks as Third-Order Autopoietic Systems}

Gunther Teubner $(1992,1993 b, 1999)$ was probably the first to conceive networks as autopoietic systems. He describes networks as third-order autopoietic systems, which re- 
sult from the re-entry of the distinction between market and hierarchy into itself (1992). Networks would be genuine emergent phenomena beyond contracts and organizations, which one cannot reduce to relationships between several autonomous corporate actors. Instead, they must be conceived as corporate actors of a special nature. Teubner identifies two sorts of networks; organization networks (conglomerates, joint ventures), and market networks (supply systems, franchising, bank transactions). Networks solve the problems of variety and redundancy of contracts and organizations. Market-based contracts are very flexible, changeable, and innovative (high variety), but "they develop little long-term orientation, forcefulness, coherence, and accumulated experience" (low redundancy) (1993b: 48). On the contrary, organizations enjoy high redundancy at the expense of variety. Unfortunately, Teubner does not specify which sort of operation these systems perform. He states that they are reducible neither to market transactions nor to organizational decisions:

The dual constitution found in its elementary acts is repeated in the network structure. Every network operation must simultaneously meet the structural requirements of both the contract between the individual actors and of the network organization as a whole. The resulting dual structure governing individual operations constitutes the specific feature of the 'network system'. By contrast with contract and organization, networks are higher-order autopoietic systems, to the extent that they set up emergent elementary acts ('network operations') through dual attribution, and link these up in a circular fashion into an operational system. (1993b: 50)

Thus, networks comprise an emergent phenomenon, performing a specific operation. This attempt to incorporate the network concept into systems theory found no resonance. A cause for this situation could be that Teubner does not provide a general network concept. He criticizes traditional interpretations, which conceive networks "as loose forms of co-operation, as decentralized co-ordination of autonomous actors, or as transitional forms between contract and organization" (53). Teubner continues noting that " $t \mathrm{t}]$ he term should be used if and only if an institutional arrangement is constituted simultaneously as a formal organization and as a contractual relation among autonomous actors" (Ibid.). This means that economic organizations and contracts should be the only appropriate context to employ the network concept, neglecting the long history of this category. Furthermore, it is impossible to deduce a general network theory from Teubner's analysis. Nevertheless, he presents some features of networks which are worth mentioning. Networks are forms of collective action which have their agency fragmented into decentralized sub-units. This means that networks accomplish their collective actions in all nodes, not through a single action center. In this sense, Teubner's network conception is highly traditional. He keeps the image of fixed nodes connected to the central one, with rigid bridges between them.

Elsewhere (1993b; 1999), Teubner suggests that "the 'state' now is being transformed into the self-description of a loose network of private and public actors" (1993a: 570). This formula completes Luhmann's formula ("Der Staat, das ist die Formel für die Selb- 
stbeschreibung des politischen Systems der Gesellschaft" [1984: 102]). However, Teubner does not explain here how this network works, and if it is a social system with its operativity, as in the previous case.

\section{Networks and Reciprocity}

After a decade of work on the network concept, Bommes and Tacke (2000, 2011a, 2011b; Tacke 2007, 2011) provide the most complete version of this category. Tacke (2000) started with the analysis of the relationship between addresses and networks. Here, Tacke resorts to Fuchs' 1997 concept of addressability, which designates the re-entry of the distinction of communication/consciousness into communication. It implies the application of the scheme inclusion/exclusion, the distinguishing between who or what is worthy of consideration and who or what is not in every communicative process. Tacke shows that the activation of addresses builds networks. In communication, it is possible to address only to individuals as persons or to organizations, which means that functional systems or interactions are not addressable and cannot take part in a network. It is also important to point out that the construction of networks presupposes the structures of functional differentiation.

In their subsequent work, Bommes and Tacke (2007) consider that social networks stay oblique to functional differentiation and organizations, as it is the factual and not the social dimension that defines the communicative possibilities of connection. Against the primacy of the factual problematization, networks oppose the primacy of social addresses (Bommes, Tacke, 2011). Nevertheless, it is important to stress that the mere reference from address to address does not create a network. The starting point of networks is, in principle, a free combinability of addresses (Bommes, Tacke, 2007). Neither formal role relationships nor materially functional ones protect this process. They depart from proposing reciprocity as their reproductive mechanism, which is a non-specific future promise of a service in return for a favor. So, the system lives with the insecurity of the acceptance of that offer. Bommes and Tacke understand that reciprocal performance expectations (reziproker Leistungserwartungen) denote the operative modus of networks $(2007,2011)$. This concept expresses the performance of services in view of prospective and indeterminate further performances. Each performance supposes a "credit" of a notalready specified counter-performance in the future. Reciprocity makes the stabilization of structures and their operational perpetuation in time possible. Nevertheless, the construction of a network cannot simply rest upon reciprocity as the general reproductive modus.

Each performance experiences its counter-performance in the future. This implies the possibility of an expansive communication of further performance expectations. A certain redundancy is likely as a condition of the increase of variations in the network. The actual generation of a counter-performance enables the formation of trust, and the observation of addresses under the viewpoint of its trustworthiness. Growth allows an accretion of the possibilities of combination, although the increase in the number and 
variation of addresses is linked to the risk of the attenuation of trust mechanisms. The closure and the limitation of participation in the network raise the mutual construction and the exclusiveness of participation, but it reduces the possible combinatory earnings. As a result, the particularity of networks is that they enable the linkage of available heterogeneous performances through reciprocity, and the constitution of a network-specific spectrum of performances.

Another important trait of networks is that they are built in a particularistic way (Tacke 2011b). Networks refer to certain persons who are mobilized as addresses to open access and possibilities. At the same time, Tacke views networks as highly precarious social processes which tend to a rapid disaggregation before they arrive at stabilization.

In most aspects, Tacke (2008) characterizes networks in contrast to organizations. The latter has no membership roles, no job postings, and no formal rules which orient the selection procedures of personnel. Networks, settled down in organizations, presuppose the inclusion in organizational membership roles, which is the mechanism that opens access to the system. Networks not only use access to organizations and functional specific performances and careers for their reproduction, they also produce exclusion. In principle, they profit from the gaps left by the inclusion universalism of organizations regarding persons. Organizations know only their selection criteria and show complete indifference concerning the individuality of persons. As a result, the particularistic orientation of networks provoke a relief from the symmetry of personal alternativity and, in this way, contributes to the absorption of insecurity in organizations.

From the beginning, Bommes and Tacke took a step back from Luhmann's idea that networks are a particularity of underdeveloped regions or remnants of ancient societal forms. Even if networks have a particularistic character, they are widespread in the entirety of world society. Moreover, reciprocity does not imply criminal, deviant, or corrupt behavior. It can lead to illegal practices, but that is not a specific trait of networks. Another fundamental aspect is that both persons and organizations can take part in them. Likewise, Bommes and Tacke eliminate the role of the mediator (Vermittler), who plays a fundamental part in Luhmann's description. This means that there is no need to think that reciprocity expectations must be managed by a broker. Mediators are particular structures which ease the stabilization of the system, making the satisfaction of the reciprocity expectations more likely, but they are not a universal trait of networks.

Alongside their theoretical formulations, Bommes and Tacke provided some examples of possible empirical applications of their new concept. One of these is Bommes' (2011) analysis of migrant networks. These networks organize transportation, lend money, provide housing and access to work, etc. Thus, networks allow migrants with a poor education and low qualifications to overcome the state inclusion barriers and work as a functional equivalent of the welfare State. In turn, Tacke (2008) analyzes the relationship between gender and networks with two empirical cases. On the one hand, she presents the networks of male university professors. Tacke argues that weekly meetings of professors to play soccer are typical occasions for social networking. As a result, this legitimate gender segregation produced by playing soccer opens the possibility of 
gender-exclusive networking, avoiding gender bias. On the other hand, Tacke inspects the case of the "Women Research Network of North Rhine-Westphalia". In this situation, the social network makes use of the functional and organizational context to obtain legitimacy and visibility. This sort of network does not contribute to the coordination or accomplishment of a research program, but it can mobilize resources from a formal organization which are not available for the network. Additionally, Tacke (2011a) provides some insight into network formation in science, art, politics, and economics.

\section{Networks as Structural Coupling}

Kämper and Schmidt (2000) understand networks as a form of structural coupling between organizations. Here, it is important to highlight that networks are the embodiment of the internal structures of an organization, and not as a relationship between different systems. The construction of networks is a reaction to the incapacity of the programs of an organization to determine the decisions of the system. However, other decision premises or the direct contact between members of different organizations can compensate for this lack. In the last case, the emerging interaction system allows that irritations will not disrupt the structures of the organization. Besides, the organizational link of expectations called "person" limits structural change. This means that there must be an agreement from other structural elements present in the organization to accomplish the change of decision premises.

Compared to Bommes and Tacke's suggestion or the history of this concept in the social sciences, this interesting contribution restricts the network concept to a very particular phenomenon. The authors do not explain why this form of structural coupling establishes a network or why the network concept should only describe a specific systemenvironment relationship between organizations. In fact, one can accept the authors' analysis regarding the change of programs in an organization and reject calling it a "network".

\section{Networks and Social Relationships}

Jan Fuhse has tried to contribute with a different conception of social networks (2003; 2009a; 2009b; 2011; 2014) which explicitly relies on Harrison White's theory. Initially, Fuhse (2003) understood that the basal elements of networks were edges or dyads. Behind a node (which can be a person or an organization), one could find a system. Here, networks could not tie on these nodes. Networks were structures of interaction which involved a multiplicity of nodes, and they comprised ties (edges). These edges were autopoietic systems, so networks were just the connection between those systems. As a result, networks were not systems as their structures were more like interrelations, which rarely have sharp limits. Fuhse's thesis supposed that the identities of persons and collectives develop in networks. 
In subsequent papers, Fuhse (2009a) radicalizes his outline, suggesting some adjustments to Luhmann's concept of communication. Communication, as a self-referential process, leads to the emergence of social systems such as interactions, organizations, functional systems, and meaningful constructions of actors and networks. Communication is always observed on the components of the utterance (Mitteilung) as the interrelated action of actors. In this way, connected expectations appear in social relations and networks. Fuhse considers social relationships as self-referential communication systems. The knotting of social relationships in the communicatively-constructed identities composes networks. Social relationships would be the basic units of networks, that is to say, the expectations formed in the communication between alter and ego. In communication, narratives develop in the relation between alter and ego, and these narratives affect the connectivity of future communication. As social systems, social relationships establish the difference between we/the rest of the environment. They are closely associated with interaction systems as they mostly arise out of interaction, and they reactivate and change in interaction. Nevertheless, social relationships extend beyond single interactive episodes. Examples of social relationships are friendship, love relationships, or enmity.

Regarding social networks, their edges are dyadic relationship systems while knots are the identities of individual, collective, and corporate actors. As a result, Fuhse defines networks as the forms which distinguish the identities in communication, and relate them. Social networks would remain oblique to interactions, organizations, social movements, functional systems, and society. Within and between these systems, identityrelated structures of expectations find a place to develop. All of these types of systems, not only interactions, can construct social networks.

This second version of the concept increases the level of complexity; at the same time, it makes some radical adjustments in Luhmann's communication theory. Examples of this are the reintroduction of action and actors into the theory, or the manipulation of the concept of utterance (Mitteilung). A crucial problem of Fuhse's scheme is that he never explains what the operative modus of social relationships is. They simply seem to be conglomerates of structures.

The place of structures is another problem. The concept of social relationships seems to be redundant. Social relationships are the expectations formed in communication between alter and ego. This concept is redundant because the expectations that would shape social relationships are the structures of the emerging system. The emerging system develops its structures and does not need any structural deposit which would preserve its structures. Whether friendship, love relationships, or enmity were social systems and not reducible to interaction systems, this would be another debate, which Fuhse does not address.

No less problematic is his network concept. In Fuhse's definition of networks as the form that distinguishes and relates the identities in communication, it is not clear how networks do this. Moreover, there is no need for such a concept to account for this phenomenon. In Luhmann's theory (1990), a twofold process handles the construction of identities: the condensation of a plurality of operations, and the confirmation of a second 
operation, which requires another situation. Identities are distinctions or forms in the Spencer-Brownian sense. This means that this concept of identity does not account for what is normally understood as the identity of a system, an actor, etc., that is, a more-orless coherent narrative regarding some fundamental traits of the subject of that discourse. This interpretation of identity would correspond, in systems theory, to the self- or heterodescriptions of a system. In this theory, the most appropriate place to "locate" identities is social memory, or the memory of each social system. For Luhmann (1995c), culture is the name that social memory assumes in the modern world. Social memory is neither a collection of psychic memories nor a conglomerate of narratives. In contrast, it is the capacity of a system to remember which side of a distinction the marked state indicated in the previous operation is on (Spencer Brown, 1972: 61). The form that assumes this process of remembrance is the utilization of a distinction. This means that social systems remember by using a distinction in an operation. As identities are a particular sort of distinctions which have experienced a certain process of condensation and confirmation, it is possible to think that they also integrate the social memory. Such a conception of identity does not match with Fuhse's idea that networks distinguish and relate identities. Identities are meaningful for the system which has generated them, but not for other systems. Likewise, it is completely obscure what relating identities would mean if they were only distinctions. As a result, if we reject Fuhse's utilization of the concept of identity, his category of social network loses its meaning.

\section{Networks as Parasites}

Different authors consider that networks are parasites. Luhmann (1995a) employs this concept to describe the relationship between networks and organizations. In Tacke's first text on the topic (2000), she concludes one should not understand networks as social systems, but as parasitic forms of structure construction. Tacke suggests that networks feed on and become stable by virtue of structures of functional differentiation. In subsequent papers, Bommes and Tacke $(2007,2011)$ mention this concept sporadically, even though Tacke (2011b) argues that they tried to conceive social networks as a specific, particularistic, and parasitic social form. They can trespass meaning contexts and system limits, and selectively link heterogeneous performances based on self-generated reciprocities. Despite that this notion of parasitism was apparently so central in their approach, they dedicated only several sentences to it, and never explained their mechanisms.

This conception of parasitism is also present in Japp's (2011) interpretation of the problem. He does not conceive of networks as systems, but as particular forms of order construction with diffuse limits and without definite rules of membership. They access a variety of function-specific performance contexts, even if they do not belong to any of these contexts. In conclusion, they parasitize in the background of functional differentiation.

Regarding the problem of parasites, Schneider and Kusche (2011) provide a more detailed explanation. The point of departure are function systems which continuously 
transform irritations into information. These systems process communication, classifying it according to their two-sided codes. In some contexts, this attribution is not immediately possible, which entails processing communication with different codes. This leads to the production of noise in the system which can turn into conflicts if no one solves the growing contradictions. These conflicts can turn into permanent sources of noise, and assume the form of a social system.

At this point, the authors distinguish two types of parasites, the unilateral type, and the reciprocal type. Parasites use noise (the waste of the production of information) as their reproductive substrate. Unilateral parasites intensify the noise and are harmful to the system, while reciprocal parasites reduce the noise and can be useful for the system. Regarding noise, Schneider and Kusche differentiate between the two modes of production of noise. There is noise coming from the non-absorbable insecurity of value attribution produced by the code, and from the rejection of the intra-system criteria of attribution in favor of criteria, which the system defines as external. Parasites of the first type are endoparasites, while the second type are ectoparasites.

The authors argue that organizations, interactions, and networks can operate as parasites. They conceive networks as interconnections of persons, organizations, and/or interaction systems. They studied the case of scientific schools as endoparasitic networks, and para-scientific networks as ectoparasites. Networks can work as parasites, but it is not clear if all networks operate in the same way.

\section{Conclusions}

In Luhmann's systems theory, the network concept appears in descriptions of the "dysfunctional" structuration of non-developed regions. The central trait of these regions is that, there, organizations do not work or they simply function as an allocation of positions. The basic structure of networks entails that those who possess a position have something to offer to a broker with whom one can interchange something. This sketchy model has found some echo among Latin American system theorists, but it has not inspired German ones who have followed distinct lines of research. In the case of Teubner, Kämper, and Schmidt, the network category was used to explain very specific phenomena, thus avoiding its insertion into the general theory. As a result, these attempts faded away in the particularity of the cases under analysis.

In contrast to these strategies, Fuhse approaches the problem from an abstract point of view, providing two solutions. The first solution turns to be highly formal and devoid of any substantial content, as he conceives networks as connections between autopoietic systems. The second solution implies substantial modifications of Luhmann's communication theory, although the consequences for the social and the general systems theory are not pondered. He re-introduces the concepts of actor, which implies re-starting the controversy over action and systems theory, as well as identity, which has a different meaning in Luhmann's theory. 
The question about networks and parasitism has been useful to shed light on a insufficiently-explored relationship. Nevertheless, this research concentrates only on one aspect of networks, and loses its meaning without a full characterization of networks as a special social system. It is only in Tacke's and Bommes' writings that we can find a complete description of networks as systems. They depart from the concept of address, which can be embodied by persons and organizations. The key mechanism of the system is reciprocity, understood as a promise of a non-specific future service in return for a favor. In this way, reciprocity links to heterogeneous performances, which allows the constitution of a network-specific spectrum of performances. Networks remain a particularistic and precarious sort of system because they refer to certain persons, and because they tend to disaggregate quickly. Moreover, networks would not be a specificity of underdeveloped regions, and are not necessarily associated with criminal behavior. In conclusion, Bommes and Tacke's network conception is the only complete and compatible account which can provide an adequate base for empirical research.

\section{References}

Alba R. (1981) From Small Groups to Social Networks. Mathematical Approaches to the Study of Group Structure. American Behavioral Scientist, vol. 24, no 5, pp. 681-694.

Azarian G. R. (2005) The General Sociology of Harrison C. White: Chaos and Order in Networks, New York: Palgrave Macmillan.

Barnes J. (1954) Class and Committees in a Norwegian Island Parish. Human Relations, vol. 7, no 1, pp. 39-58.

Bommes M. (2011) Migrantennetzwerke in der funktional differenzierten Gesellschaft. Netzwerke in der funktional differenzierten Gesellschaft (eds. M. Bommes, V. Tacke), Wiesbaden: VS, pp. 241-260.

Bommes M., Tacke V. (2007) Netzwerke in der „Gesellschaft der Gesellschaft": Funktionen und Folgen einer doppelten Begriffsverwendung. Soziale Systeme, vol. 13, no 1-2, pp. 9-20.

Bommes M., Tacke V. (2011) Das Allgemeine und das Besondere des Netzwerkes. Netzwerke in der funktional differenzierten Gesellschaft (eds. M. Bommes, V. Tacke), Wiesbaden: VS, pp. 25-50.

Bott E. (1955) Urban Families: Conjugal Roles and Social Networks. Human Relations, vol. 8, no 4, pp. 345-384.

Bott E. (2001) Family and Social Network: Roles, Norms and External Relationships in Ordinary Urban Families, London: Routledge.

Foerster H. von (2003) What is Memory that it May Have Hindsight and Foresight as Well? Understanding Understanding: Essays on Cybernetics and Cognition, New York: Springer, pp. 101-131.

Fuchs P. (1997) Adressabilität als Grundbegriff der soziologischen Systemtheorie. Soziale Systeme, vol. 3, pp. 57-79. 
Fuhse J. (2003) Systeme, Netzwerke, Identitäten die Konstitution sozialer Grenzziehungen am Beispiel amerikanischer Straßengangs, Stuttgart: Universität Stuttgart.

Fuhse J. (2009a) Die kommunikative Konstruktion von Akteuren in Netzwerken. Soziale Systeme, vol. 15, no 2, pp. 288-316.

Fuhse J. (2009b) The Meaning Structure of Social Networks. Sociological Theory, vol. 27, no 1 , pp. 51-73.

Fuhse J. (2011) Kommunikation und Handeln in Netzwerken. Systemische Soziale Arbeit, vol. 2-3, pp. 25-39.

Fuhse J. (2014) Verbindungen und Grenzen. Soziale Netzwerke: Konzepte und Methoden der sozialwissenschaftlichen Netzwerkforschung (ed. J. Weyer), Oldenbourg: De Gruyter, pp. 291-313.

Granovetter M. (1973) The Strength of Weak Ties. American Journal of Sociology, vol. 78, no 6, pp. 1360-1380.

Granovetter M. (1976) Network Sampling: Sorne First Steps. American Journal of Sociology, vol. 81, no 6, pp. 1287-1303.

Granovetter M. (1983) The Strength of Weak Ties: A Network Theory Revisited. Sociological Theory, vol. 1, pp. 201-233.

Japp K. (2011) Zur Bedeutung von Vertrauensnetzwerken für die Ausdifferenzierung politischer Kommunikation. Netzwerke in der funktional differenzierten Gesellschaft (eds. M. Bommes, V. Tacke), Wiesbaden: VS, pp. 261-286.

Kämper E., Schmidt J. (2000) Netzwerke als strukturelle Kopplung; Systemtheoretische: Überlegungen zum Netzwerkbegriff. Soziale Netzwerke: Konzepte und Methoden der sozialwissenschaftlichen Netzwerkforschung (ed. J. Weyer), Oldenbourg: Oldenbourg Wissenschaftsverlag, pp. 211-235.

Latour B. (1996) On Actor-Network Theory: A Few Clarifications. Soziale Welt, vol. 47, no 4 , pp. 369-381.

Latour B. (1999) On Recalling ANT. Sociological Review, vol. 47, no S1, pp. 15-25.

Law J. (1999) After ANT: Complexity, Naming and Topology. Sociological Review, vol. 47, no $\mathrm{S}_{1}, \mathrm{pp} .1-14$.

Luhmann N. (1984) Staat und Politik: Zur Semantik der Selbstbeschreibung politischer Systeme. Politische Theoriengeschichte: Probleme einer Teildisziplin der Politischen Wissenschaft (ed. U. Bermbach), Wiesbaden: VS, pp. 99-125.

Luhmann N. (1990) Identität - was oder wie? Soziologische Aufklärung 5: Konstruktivistische Perspektiven, Opladen: Westdeutscher Verlag, pp. 14-30.

Luhmann N. (1992) Zur Einführung. Neves M., Verfassung und Positivität des Rechts in der peripheren Moderne: Eine theoretische Betrachtung und eine Interpretation des Falls Brasilien, Berlin: Duncker \& Humblot, pp. 1-4.

Luhmann N. (1995a) Inklusion und Exklusion. Soziologische Aufklärung 6: Die Soziologie und der Mensch, Opladen: Westdeutscher Verlag, pp. 237-264.

Luhmann N. (1995b) Kausalität im Süden. Soziale Systeme, vol. 1, pp. 7-28. 
Luhmann N. (1995c) Kultur als historischer Begriff. Gesellschaftsstruktur und Semantik: Studien zur Wissenssoziologie der modernen Gesellschaft, Band 4, Frankfurt am Main: Suhrkamp, pp. 31-54.

Luhmann N. (2012) Theory of Society, Stanford: Stanford University Press.

Mische A., White H. (1998) Between Conversation and Situation: Public Switching Dynamics across Network Domains. Social Research, vol. 65, no 3, pp. 695-724.

Mitchell J.C. (1974) Social Networks. Annual Review of Anthropology, vol. 3, pp. 279-299.

Radcliffe-Brown A. (1940) On Social Structure. Journal of the Royal Anthropological Institute of Great Britain and Ireland, vol. 70, no 1, pp. 1-12.

Schneider W. L., Kusche I. (2011) Parasitäre Netzwerke in Wissenschaft und Politik. Netzwerke in der funktional differenzierten Gesellschaft (eds. M. Bommes, V. Tacke), Wiesbaden: VS, pp. 173-210.

Spencer Brown G. (1972) Laws of Form, New York: The Julian Press.

Tacke V. (2000) Netzwerk und Adresse. Soziale Systeme, vol. 6, pp. 291-320.

Tacke V. (2008) Neutralisierung, Aktualisierung, Invisibilisierung: Zur Relevanz von Geschlecht in Systemen und Netzwerken. Geschlechterdifferenzen - Geschlechterdifferenzierungen (ed. S. Wilz), Wiesbaden: VS, pp. 253-290.

Tacke V. (2011a) Soziale Netzwerkbildung in Funktionssystemen der Gesellschaft: Vergleichende Perspektiven. Netzwerke in der funktional differenzierten Gesellschaft (eds. M. Bommes, V. Tacke), Wiesbaden: VS, pp. 89-117.

Tacke V. (2011b) Systeme und Netzwerke - oder: Was man an sozialen Netzwerken zu sehen bekommt, wenn man sie systemtheoretisch beschreibt. Systemische Soziale Arbeit, vol. 2-3, pp. 6-24.

Teubner G. (1992) Die vielköpfige Hydra: Netzwerke als kollektive Akteure höherer Ordnung. Emergenz: Die Entstehung von Ordnung, Organisation und Bedeutung (eds. W. Krohn, G. Küppers), Frankfurt am Main: Suhrkamp, pp. 189-216.

Teubner G. (1993a) The "State" of Private Networks: The Emerging Legal Regime of Polycorporatism in Germany. Brigham Young University Law Review, vol. 2, pp. 553-575.

Teubner G. (1993b) The Many-Headed Hydra: Networks as Higher-Order Collective Actors. Corporate Control and Accountability: Changing Structures and the Dynamics of Regulation (eds. J. McCahery, S. Picciotto, C. Scott), Oxford: Oxford University Press, pp. 41-60.

Teubner G. (1999) Polykorporatismus: Der Staat als Netzwerk öffentlicher und privater Kollektivakteure. Das Recht der Republik (eds. H. Brunkhorst, P. Niesen), Frankfurt am Main: Suhrkamp, pp. 346-372. 


\section{Социальные сети и теория систем}

\section{Сантьяго Габриэль Кализе}

Исследователь, CONICET (National Scientific and Technical Research Council), Университет Буэнос-Айреса, факультет социальных наук, Instituto de Investigaciones Gino Germani (IIGG)

Адрес: Uriburu $9506^{\circ}$ Floor, Ciudad de Buenos Aires, Argentina C1114AAD

E-mail: c_santiago_g200o@yahoo.com.ar

Статья критически рассматривает концепции социальных сетей в рамках теории систем. Предполагается, что либо социальные сети могут трактоваться как системы, либо подобное видение невозможно. Во втором случае сети понимаются как структурные сопряженности (Кампер и Шмидт) или как формы (Фухс). Среди тех, кто разделяет первый подход, - Луман, использовавший понятие «социальных сетей» для описания особенности социетальной структуры в неразвитых регионах, но он не погружался в теоретическую разработку понятия. Трактовка Тёбнера также связана с частным случаем без попыток сформулировать общую сетевую теорию. Для Боммса и Таке центральным механизмом, который связывает различные сетевые адреса (личности или организации) через неспецифическое ожидание возможного вознаграждения за услугу, является реципрокность. Анализ показывает, что данное описание дает самое полное представление о понятии, оставаясь полностью совместимым с системной теорией.

Ключевые слова: реципрокность, структурные сопряженности, сетевой адрес, социальные отношения, организации, паразит 